\title{
Cloud droplet activation of mixed organic-sulfate particles produced by the photooxidation of isoprene
}

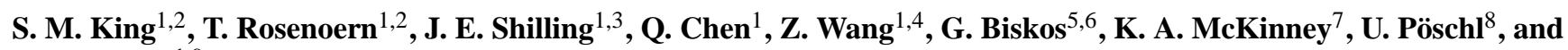 \\ S. T. Martin ${ }^{1,9}$ \\ ${ }^{1}$ School of Engineering and Applied Sciences, Harvard University, Cambridge, Massachusetts, USA \\ ${ }^{2}$ now at: Department of Chemistry, University of Copenhagen, Copenhagen, Denmark \\ ${ }^{3}$ now at: Atmospheric Sciences and Global Change Division, Pacific Northwest National Laboratory, Richland, \\ Washington, USA \\ ${ }^{4}$ now at: Environmental Research Institute, Shandong University, Shandong, China \\ ${ }^{5}$ Department of Environment, University of the Aegean, Mytilene, Greece \\ ${ }^{6}$ Faculty of Applied Sciences, Delft University of Technology, Delft, The Netherlands \\ ${ }^{7}$ Department of Chemistry, Amherst College, Amherst, Massachusetts, USA \\ ${ }^{8}$ Max Planck Institute for Chemistry, Biogeochemistry Department, Mainz, Germany \\ ${ }^{9}$ Department of Earth and Planetary Sciences, Harvard University, Cambridge, Massachusetts, USA
}

Received: 25 November 2009 - Published in Atmos. Chem. Phys. Discuss.: 7 January 2010

Revised: 22 March 2010 - Accepted: 13 April 2010 - Published: 27 April 2010

\begin{abstract}
The cloud condensation nuclei (CCN) properties of ammonium sulfate particles mixed with organic material condensed during the hydroxyl-radical-initiated photooxidation of isoprene $\left(\mathrm{C}_{5} \mathrm{H}_{8}\right)$ were investigated in the continuous-flow Harvard Environmental Chamber. CCN activation curves were measured for organic particle mass concentrations of 0.5 to $10.0 \mu \mathrm{g} \mathrm{m}^{-3}, \mathrm{NO}_{\mathrm{x}}$ concentrations from under $0.4 \mathrm{ppbv}$ up to $38 \mathrm{ppbv}$, particle mobility diameters from 70 to $150 \mathrm{~nm}$, and thermodenuder temperatures from 25 to $100^{\circ} \mathrm{C}$. At $25^{\circ} \mathrm{C}$, the observed $\mathrm{CCN}$ activation curves were accurately described by a Köhler model having two internally mixed components, namely ammonium sulfate and secondary organic material. The modeled physicochemical parameters of the organic material were equivalent to an effective hygroscopicity parameter $\kappa_{\mathrm{ORG}}$ of $0.10 \pm 0.03$, regardless of the $\mathrm{C}_{5} \mathrm{H}_{8}: \mathrm{NO}_{\mathrm{x}}$ concentration ratio for the span of $>200: 0.4$ to 50:38 (ppbv:ppbv). The volatilization curves (i.e., plots of the residual organic volume fraction against temperature) were also similar for the span of investigated $\mathrm{C}_{5} \mathrm{H}_{8}: \mathrm{NO}_{\mathrm{x}}$ ratios, suggesting a broad similarity of particle chemical composition. This suggestion was supported by limited variance at $25^{\circ} \mathrm{C}$ among the particle mass spectra. For example, the signal intensity at $\mathrm{m} / \mathrm{z} 44$ (which can result from the fragmentation of oxidized molecules believed
\end{abstract}

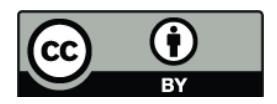

Correspondence to: $\mathrm{S}$. T. Martin (scot_martin@ harvard.edu) to affect hygroscopicity and $\mathrm{CCN}$ properties) varied weakly from 6 to $9 \%$ across the range of investigated conditions. In contradistinction to the results for $25^{\circ} \mathrm{C}$, conditioning up to $100^{\circ} \mathrm{C}$ in the thermodenuder significantly reduced CCN activity. The altered CCN activity might be explained by chemical reactions (e.g., decomposition or oligomerization) of the secondary organic material at elevated temperatures. The study's results at $25^{\circ} \mathrm{C}$, in conjunction with the results of other chamber and field studies for a diverse range of conditions, suggest that a value of $0.10 \pm 0.05$ for $\kappa_{\mathrm{ORG}}$ is representative of both anthropogenic and biogenic secondary organic material. This finding supports the use of $\kappa_{\mathrm{ORG}}$ as a simplified yet accurate general parameter to represent the CCN activation of secondary organic material in large-scale atmospheric and climate models.

\section{Introduction}

The growth of atmospheric particles to form cloud droplets influences climate through indirect effects on cloud brightness and lifetime and changes in patterns of precipitation (Lohmann and Feichter, 2005; IPCC, 2007; Andreae and Rosenfeld, 2008). Predictions of which atmospheric particles act as cloud condensation nuclei $(\mathrm{CCN})$ (i.e., the initial particles on which water condenses to grow into droplets) are complicated by their diverse composition (McFiggans et

Published by Copernicus Publications on behalf of the European Geosciences Union. 
al., 2006). In particular, the influence of organic material on $\mathrm{CCN}$ activity is both important and challenging, given that organic material at times comprises a dominant fraction of the particle mass but consists of myriad possible molecular configurations (Andreae and Crutzen, 1997; Kanakidou et al., 2005; Murphy et al., 2006; Goldstein and Galbally, 2007; Zhang et al., 2007). Moreover, less-active organic material is often internally mixed with more-active inorganic material within a single particle so that an understanding of the $\mathrm{CCN}$ activity of mixed materials is required (Shulman et al., 1996; Kulmala et al., 1997; Cruz and Pandis, 1998; Laaksonen et al., 1998; Bilde and Svenningsson, 2004; Sun and Ariya, 2006).

A significant fraction of the organic material in atmospheric particles results from the gas-to-particle condensation of the low-volatility oxidation products of volatile organic compounds (VOCs), thereby forming a secondary organic aerosol (SOA) (Seinfeld and Pandis, 2006). Similar oxidation products can also form by aqueous chemical pathways, such as in cloud droplets (Lim et al., 2005; Volkamer et al., 2009), and they can remain in the particle following droplet evaporation. Globally, the dominant contributors to SOA production are biogenic VOCs, such as terpenes and isoprene (Griffin et al., 1999; Chung and Seinfeld, 2002; Tsigaridis and Kanakidou, 2003; Kanakidou et al., 2005). Isoprene is the most abundant non-methane hydrocarbon, with emissions of ca. $500 \mathrm{Tg} \mathrm{yr}^{-1}$ (Guenther et al., 2006), and the contribution of isoprene emissions to tropospheric organic particle mass concentrations can be significant (Claeys et al., 2004; Edney et al., 2005; Henze and Seinfeld, 2006; Kleindienst et al., 2006; Kroll et al., 2006; Ng et al., 2008; Carlton et al., 2009).

In the present study, the $\mathrm{CCN}$ activity of mixed organicsulfate particles, which were produced by the condensation of isoprene photooxidation products on sulfate seed particles at variable $\mathrm{NO}_{\mathrm{x}}$ concentrations, was investigated in the Harvard Environmental Chamber. The influence of $\mathrm{NO}_{\mathrm{x}}$ concentration on the yield of particle mass for isoprene photooxidation was reported previously (Presto et al., 2005; Dommen et al., 2006; Kroll et al., 2006; Carlton et al., 2009), and the observed changes in yield reported in those studies for varying VOC-to- $\mathrm{NO}_{\mathrm{x}}$ ratios suggested significant variability in the chemical composition of secondary organic material. This variability, which we hypothesized could imply changes in CCN activity, provided our motivation for the study described herein. CCN activity after conditioning in a thermodenuder was also measured in the present study. Particle conditioning by use of thermodenuders has been discussed in several recent laboratory studies (Paulsen et al., 2006; An et al., 2007; Jonsson et al., 2007; Stanier et al., 2007), and the reported effects on hygroscopic properties motivated us in this study to test for significant changes in $\mathrm{CCN}$ activity (Meyer et al., 2009; Poulain et al., 2009).

\section{Experimental}

The Harvard Environmental Chamber (HEC) consists of a $4.7 \mathrm{~m}^{3}$ Teflon bag outfitted with lines for chemical flows in and out of the bag as well as for sampling and analysis by instrumentation (Shilling et al., 2008; King et al., 2009). The bag is within a temperature-controlled housing. In the present study, the HEC was used to form mixed organicsulfate particles by the condensation of the products of isoprene photooxidation onto inorganic seed particles (Fig. 1). Continuous-flow operation of the chamber held reaction conditions at steady state over time periods of days, allowing for adequate signal integration and averaging at low mass concentrations. The conditions of each experiment performed during this study are listed in Table 1 . The temperature and the relative humidity in the bag were held at $25 \pm 1{ }^{\circ} \mathrm{C}$ and $40 \pm 2 \%$, respectively, by feedback control (King et al., 2009). Ultraviolet irradiation was provided by forty-eight 40-W Sylvania 350BL blacklights affixed to the chamber walls. The photolysis rate coefficient of $\mathrm{NO}_{2}$ was measured as $0.23 \pm 0.01 \mathrm{~min}^{-1}$.

The Teflon bag inside the chamber was cleaned before each experiment, typically for one to two days. During the cleaning procedure, the bag was irradiated and the temperature of the chamber was set to $40^{\circ} \mathrm{C}$. Continuous flows of particle- and hydrocarbon-free air at $50 \mathrm{sLpm}$ and of hydrogen peroxide (vide infra) at $0.5 \mathrm{sLpm}$ were flushed through the chamber, for which the conditions of the standard liter (sL) were $273.15 \mathrm{~K}$ and $10^{5} \mathrm{~Pa}$. Cleaning continued until the particle concentration was less than $1 \mathrm{~cm}^{-3}$ and the $\mathrm{NO}_{\mathrm{x}}$ concentration was less than 1 ppbv.

The components injected into the chamber included dry and humid pure air, dry ammonium sulfate seed particles, hydrogen peroxide $\left(\mathrm{H}_{2} \mathrm{O}_{2}\right)$, isoprene $\left(\mathrm{C}_{5} \mathrm{H}_{8}\right)$, and nitric oxide (NO). Flow into the chamber included $17 \mathrm{sLpm}$ of mixed wet and dry clean air, $0.5 \mathrm{sLpm}$ of air exiting the $\mathrm{H}_{2} \mathrm{O}_{2}$ bubbler, and $2.3 \mathrm{sLpm}$ from the seed-particle generator (TSI Model 3076). For this total flow, the mixed-volume residence time in the bag was $3.6 \mathrm{~h}$ at $25^{\circ} \mathrm{C}$. Isoprene flow ranged from 0.01 to $0.04 \mathrm{sLpm}$, depending on the desired steady-state organic particle mass concentration. For experiments with variable $\mathrm{NO}_{\mathrm{x}}$, NO flow was less than $0.01 \mathrm{sLpm}$. The seed particles were passed through a diffusion dryer $(<5 \% \mathrm{RH})$ and size-selected by a differential mobility analyzer $\left(\mathrm{DMA}_{1}\right.$, TSI Model 3071) before they were injected into the chamber. The size distribution of the dry seed particles had a mean electric mobility that was equivalent to $50 \mathrm{~nm}$ spherical particles of +1 charge (i.e., $D_{\mathrm{m},+1}=50 \mathrm{~nm}$ ). The geometric standard deviation of the distribution was approximately 1.3 , in line with the employed sheath-to-aerosol flow ratio of 10:2.5. The particle number concentration exiting the bag ranged between 4000 and $8000 \mathrm{~cm}^{-3}$.

Injection of the $\mathrm{H}_{2} \mathrm{O}_{2}$ radical precursor used in these experiments followed the method of Kroll et al. (2006), who described SOA production by $\mathrm{OH}$-initiated VOC oxidation. 


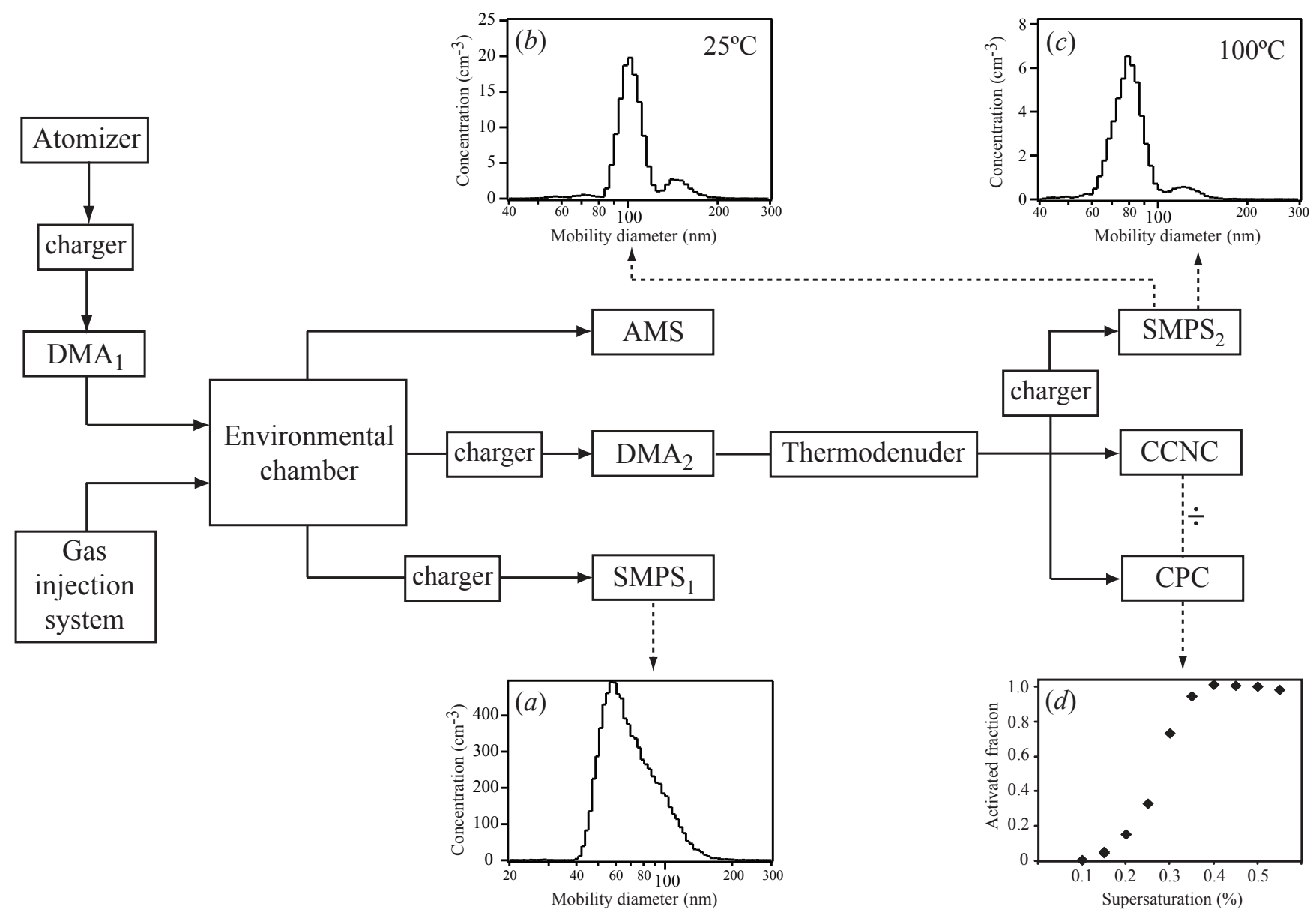

Fig. 1. Schematic diagram of the experimental setup for the study of CCN activity of the secondary organic material produced by the photooxidation of isoprene. Panels show examples of collected data: (a) A number-diameter distribution of particles exiting the chamber. (b) A number-diameter distribution of particles after selection by $\mathrm{DMA}_{2}$ and passage through the thermodenuder at $25^{\circ} \mathrm{C}$ (cf. further examples in Fig. 2). (c) A number-diameter distribution after passage through the thermodenuder at $100^{\circ} \mathrm{C}$. (d) A CCN activation curve. Legend: AMS, aerosol mass spectrometer; CCNC, cloud condensation nucleus counter; CPC, condensation particle counter; DMA, differential mobility analyzer; and SMPS, scanning mobility particle sizer.

A flow of $0.5 \mathrm{sLpm}$ of nitrogen was introduced by a fritted stainless steel bubbler into a concentrated aqueous solution of $\mathrm{H}_{2} \mathrm{O}_{2}$ (50 wt\%; Sigma Aldrich), and the exit flow of $\mathrm{H}_{2} \mathrm{O}_{2}$-laden $\mathrm{N}_{2}$ was injected into the bag through a PFA tube. Based on the $\mathrm{H}_{2} \mathrm{O}_{2}$ vapor pressure of the solution (Scatchard et al., 1952), the predicted steady-state concentration of $\mathrm{H}_{2} \mathrm{O}_{2}$ in the bag was 22 ppmv prior to photolysis. Photolysis of $\mathrm{H}_{2} \mathrm{O}_{2}$ was enhanced by irradiation from an ultraviolet lamp (Jelight 1000) prior to injection into the irradiated bag.

Isoprene injection was regulated using a mass flow controller attached to a gas cylinder (Air Liquide; 0.5, 5, and $100 \mathrm{ppmv}$ ). Isoprene concentrations in the bag prior to reaction (cf. Table 1) were calculated from the dilution of the cylinder concentrations. The accuracy of the calculated concentrations was verified experimentally by use of an Ionicon proton-transfer reaction mass spectrometer (PTR-MS).
The calculations and the measurements agreed within a $10 \%$ uncertainty (e.g., the calculated $50 \mathrm{ppbv}$ was measured as $48 \pm 5 \mathrm{ppbv}$ ). Measurements for an initial isoprene concentration of $50 \mathrm{ppbv}$ and $\mathrm{NO}_{\mathrm{x}}$ concentration of less than $1 \mathrm{ppbv}$ during steady-state photolysis showed that $10 \%$ of the isoprene exited without reaction, implying an effective $\mathrm{OH}$ concentration of $7 \times 10^{6}$ molecule $\mathrm{cm}^{-3}$ for an $\mathrm{OH}-\mathrm{C}_{5} \mathrm{H}_{8}$ bimolecular rate constant of $1.02 \times 10^{-10} \mathrm{~cm}^{3}$ molecule ${ }^{-1} \mathrm{~s}^{-1}$ (Lei et al., 2000). Initial isoprene concentrations of 50 to 200 ppbv were employed in the experiments (cf. Table 1).

The $\mathrm{NO}_{\mathrm{x}}$ concentration was maintained in the bag by constant injection of NO from a gas cylinder (Air Liquide; 1 and $5 \mathrm{ppm}$ ). For Experiment 1, no prior injection of NO had occurred since the installation of the bag. During this experiment, the $\mathrm{NO}_{\mathrm{x}}$ concentration remained below the detection limit of 0.4 ppbv (Teledyne 200E chemiluminescent analyzer). 
Table 1. Conditions of the seven experiments described in this study for the photooxidation of isoprene. Isoprene concentrations are listed prior to reaction. Concentrations of $\mathrm{NO}_{\mathrm{x}}, \mathrm{O}_{3}$, and organic particle mass were measured at steady state. Mass yield is based on an estimate that $90 \%$ of isoprene reacts. The columns " $\mathrm{m} / z 44$ " and " $\mathrm{CO}_{2}^{+}$" represent the percent contribution to the total organic mass spectrum of the particles (as recorded by the HR-ToF-AMS), where $\mathrm{CO}_{2}^{+}$is determined from the high-resolution data and $m / z$, 44 is from the unit-mass resolution data and includes contributions both from $\mathrm{CO}_{2}^{+}$and $\mathrm{C}_{2} \mathrm{H}_{4} \mathrm{O}^{+}$.

\begin{tabular}{|c|c|c|c|c|c|c|c|c|}
\hline \multirow[b]{2}{*}{$\begin{array}{c}\text { Experiment } \\
\text { number }\end{array}$} & \multirow[b]{2}{*}{$\begin{array}{l}\text { Time } \\
\text { period }\end{array}$} & \multicolumn{2}{|c|}{ Controlled conditions } & \multicolumn{5}{|c|}{ Secondary conditions } \\
\hline & & $\begin{array}{l}\text { Calculated } \\
\text { isoprene } \\
\text { concentration } \\
\text { (ppbv; injected) }\end{array}$ & $\begin{array}{l}\mathrm{NO}_{\mathrm{x}} \\
(\mathrm{ppbv})\end{array}$ & $\begin{array}{l}\mathrm{O}_{3}{ }^{* * *} \\
(\mathrm{ppbv})\end{array}$ & $\begin{array}{c}\text { Organic } \\
\text { particle mass } \\
\left(\mu \mathrm{g} \mathrm{m}^{-3}\right)\end{array}$ & $\begin{array}{c}\text { Organic } \\
\text { particle mass } \\
\text { yield }(\%)^{* * * *}\end{array}$ & $\begin{array}{c}m / z 44 \\
(\%)\end{array}$ & $\begin{array}{r}\mathrm{CO}_{2}^{+} \\
(\%)\end{array}$ \\
\hline 1 & 9-11 Oct 2008 & 200 & $<0.4^{*}$ & $19 \pm 4.5$ & 7.0 & 1.4 & 6 & 5 \\
\hline 2 & $18-20$ Oct 2008 & 100 & $0.51 \pm 0.47$ & $39 \pm 4.3$ & 7.7 & 3.1 & 6 & 5 \\
\hline 3 & 28-31 Oct 2008 & 50 & $1.2 \pm 0.46$ & $36 \pm 1.9$ & 0.5 & 0.4 & 9 & 8 \\
\hline 4 & 3-4 Nov 2008 & 200 & $2.3 \pm 0.55$ & $45 \pm 1.8$ & 10.0 & 2.0 & 7 & 6 \\
\hline 5 & 25 Nov 2008 & 50 & $17 \pm 3.3$ & $68 \pm 7.3$ & 1.2 & 0.9 & 8 & 7 \\
\hline $6^{* *}$ & 4-5 Dec 2008 & 50 & $27 \pm 0.74$ & $221 \pm 2.4$ & 0.6 & 0.5 & 7 & 6 \\
\hline 7 & 14 Dec 2008 & 50 & $38 \pm 5.4$ & $332 \pm 3.0$ & $\mathrm{n} / \mathrm{a}$ & $\mathrm{n} / \mathrm{a}$ & $\mathrm{n} / \mathrm{a}$ & $\mathrm{n} / \mathrm{a}$ \\
\hline
\end{tabular}

* 0.4 ppbv is the minimum detection limit of the instrumentation.

** No CCN data are available for experiment 6.

*** Concentrations of $\mathrm{O}_{3}$ are an upper limit because interference from absorption at $254 \mathrm{~nm}$ by hydrogen peroxide is not taken into account.

**** Lower limit of yield because no corrections were made for wall loss.

The concentration of $\mathrm{O}_{3}$, produced as a by-product of VOC photooxidation, was recorded using an ultraviolet absorption ozone analyzer (Teledyne 400E). The concentration increased linearly with the $\mathrm{NO}_{\mathrm{x}}$ concentration, ranging from $19 \pm 5$ to $333 \pm 3$ ppbv $\mathrm{O}_{3}$ for $\mathrm{NO}_{\mathrm{x}}$ concentrations ranging from less than $1 \mathrm{ppbv}$ to $38 \pm 5 \mathrm{ppbv}$ (Table 1). The ozonolysis products of the isoprene have high volatility and are not expected to contribute to the particle mass concentrations (Kleindienst et al., 2007).

The flow exiting the bag was split three ways for simultaneous sampling by a scanning mobility particle sizer (SMPS $_{1}$, TSI Model 3936) to measure the particle numbersize distributions, an Aerodyne high-resolution time-of-flight aerosol mass spectrometer (HR-ToF-AMS) to measure the organic and sulfate particle mass concentrations, and a CCN instrument configuration to measure the size-resolved activation spectra. The $\mathrm{CCN}$ measurements were carried out by the instrument chain represented in Fig. 1. A differential mobility analyzer $\left(\mathrm{DMA}_{2}\right.$, sheath-to-aerosol flow ratio of 10:2.5) was used to select particles within a confined range of electrical mobility. For the experiments described herein, selected mode diameters included $D_{\mathrm{m},+1}$ equivalents of 70,80 , $90,100,120$, and $150 \mathrm{~nm}$. The mobility-classified particles flowed through a thermodenuder before simultaneous sampling by a condensation particle counter (CPC, TSI 3010), a Droplet Measurement Technologies cloud condensation nucleus counter (CCNC, DMT CCN-2) (Roberts and Nenes, 2005; Lance et al., 2006; Rose et al., 2008), and a second SMPS (SMPS 2 , DMA sheath-to-aerosol ratio of 10:1).
The activated fraction was calculated as the number concentration of particles growing to optical diameters of $1 \mu \mathrm{m}$ and larger, divided by the number concentration measured by the CPC. Calibration of the CCNC was performed offline by using an osmotic coefficient model with the parameterization of Brechtel and Kreidenweis (2000) to determine the activation supersaturations of $\left(\mathrm{NH}_{4}\right)_{2} \mathrm{SO}_{4}$ (Shilling et al., 2007). SMPS $_{2}$ with a particle charger in front measured the number-diameter distribution of particles entering the CCNC (cf. Fig. 2) and allowed for direct incorporation of the effects of multiply charged particles in the data analysis.

The thermodenuder (TSI Model 3065) consisted of a heated section ( $25 \mathrm{~cm}$ length), in which molecules were evaporated from the particles, followed by an absorptive section ( $80 \mathrm{~cm}$ length), in which the evaporated molecules were removed by activated charcoal. The flow rate through the thermodenuder was maintained below the maximum recommendation of $3 \mathrm{Lpm}$, corresponding to a residence time of more than $0.6 \mathrm{~s}$ in the heated section and more than $1.9 \mathrm{~s}$ in the absorptive section.

\section{Results and discussion}

The critical supersaturation $S_{\mathrm{c}}(\%)$ of $\mathrm{CCN}$ activation for a particle corresponds to the maximum in the supersaturation $S$ of the hygroscopic growth curve (Seinfeld and Pandis, 2006). For multi-component particles, this curve can be calculated 


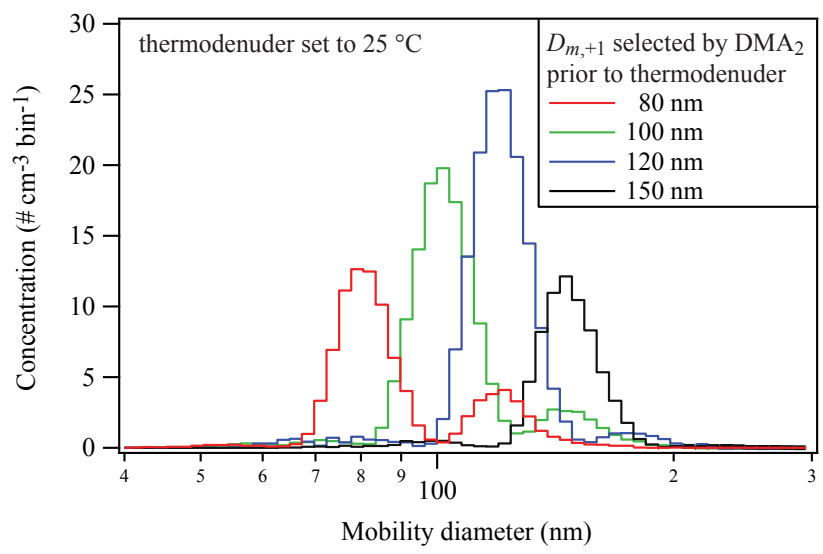

Fig. 2. Number-diameter distributions $\left(\# \mathrm{~cm}^{-3} \mathrm{bin}^{-1}\right)$ measured by $\mathrm{SMPS}_{2}$ for different settings of DMA 2 in Experiment 2 for a thermodenuder setting of $25^{\circ} \mathrm{C}$. Shoulders on the distributions at mobility diameters greater than the selected $D_{\mathrm{m},+1}$ are apparent, arising from doubly charged particles that pass $\mathrm{DMA}_{2}$ and are measured by SMPS $_{2}$ after recharging.

as follows (King et al., 2009):

$$
1+\frac{S}{100}=\frac{n_{\mathrm{w}} \exp \left(\frac{4 \sigma V_{\mathrm{m}, \mathrm{w}}}{\mathrm{RTD}_{\mathrm{aq}}}\right)}{\left(n_{\mathrm{w}}+\frac{\pi D_{\text {geo,dry }}^{3}}{6} \sum_{k \in(\mathrm{AS}, \mathrm{ORG})} \varepsilon_{\mathrm{k}} \omega_{\mathrm{k}} i_{\mathrm{k}} V_{\mathrm{m}, \mathrm{k}}^{-1}\right)}
$$

where $n_{\mathrm{w}}$ is the number of moles of water, $\varepsilon_{\mathrm{k}}$ is the volume fraction of species $\mathrm{k}$ in the dry particle, $\omega_{\mathrm{k}}$ is the soluble fraction of species $k$ at activation, $i_{\mathrm{k}}$ is the van't Hoff factor of the soluble fraction of species $k$ in solution, $V_{\mathrm{m}, \mathrm{k}}$ is the molar volume of the soluble fraction of species $k$ in the dry particle, $\sigma$ is the surface tension of the solution, subscript $\mathrm{w}$ is pure water, $R$ is the universal gas constant, $T$ is temperature, $D_{\text {geo,dry }}$ is the geometric diameter of the dry particle, and $D_{\text {aq }}$ is the diameter of the wet particle. In our study, species $k$ include ammonium sulfate ("AS") and secondary organic material ("ORG").

As apparent in Eq. (1), the terms $\omega_{\mathrm{ORG}}, i_{\mathrm{ORG}}$, and $V_{\mathrm{m}, \mathrm{ORG}}$ appear together so that compensating changes in them can explain a CCN data set, implying that these terms are nonunique. Petters and Kreidenweis (2007) developed a lumpedparameter approach as a way to represent the chemical properties that influence $\mathrm{CCN}$ activation. According to this approach, the hygroscopic growth curve can be expressed using the effective hygroscopicity parameter $\kappa_{\mathrm{k}}$ as follows:

$$
1+\frac{S}{100}=\frac{\left(D_{\mathrm{aq}}^{3}-D_{\mathrm{geo}, \mathrm{dry}}^{3}\right) \exp \left(\frac{4 \sigma V_{\mathrm{m}, \mathrm{w}}}{\mathrm{RTD}_{\mathrm{aq}}}\right)}{D_{\mathrm{aq}}^{3}-D_{\text {geo,dry }}^{3}\left(1-\sum_{\mathrm{k}} \varepsilon_{\mathrm{k}} \kappa_{\mathrm{k}}\right)}
$$

for which $\sigma=0.072 \mathrm{~N} \mathrm{~m}^{-1}$ of water. Equations (1) and (2) are related by $\kappa_{\mathrm{k}}=\omega_{\mathrm{k}} i_{\mathrm{k}} V_{\mathrm{m}, \mathrm{k}}^{-1} V_{\mathrm{m}, \mathrm{w}}$.
$\mathrm{CCN}$ activation curves measured with the thermodenuder at $25^{\circ} \mathrm{C}$ are shown in Fig. 3 for particle populations having $D_{\mathrm{m},+1}$ between 70 and $150 \mathrm{~nm}$. The range of $\mathrm{C}_{5} \mathrm{H}_{8}: \mathrm{NO}_{\mathrm{x}}$ conditions represented in Fig. 3 corresponds to the experiments described in Table 1. The lines through the data points show the predicted CCN activation curves of the particle population based on the model described in King et al. (2009). ${ }^{1}$ In the model, particles within the population have different critical supersaturations because of heterogeneities in particle diameter and organic volume fraction. One underlying source of heterogeneity is the distribution of diameters for the sulfate seed particles, which arises from both the resolution of $\mathrm{DMA}_{1}$ and the presence of multiply charged particles. For similar reasons, there is heterogeneity in the particles that exit $\mathrm{DMA}_{2}$. These heterogeneities explain the inflection point apparent in the predicted activation curves (as well as in the data) shown in Fig. 3.

The predicted activation curves, which pass through all data points within experimental uncertainty, are based on a single set of physicochemical parameters (Table 2) across the range of investigated $\mathrm{C}_{5} \mathrm{H}_{8}: \mathrm{NO}_{\mathrm{x}}$ conditions (i.e., 200:0 to $50: 38 \mathrm{ppbv}$ ). To obtain the parameters in Table 2, we prescribed all quantities except for the effective molar volume $V_{\mathrm{m}, \mathrm{ORG}}$ of the organic component (King et al., 2007). This quantity was optimized in a least-squares manner so that the model predictions fit the observations, and the result of $180 \mathrm{~cm}^{3} \mathrm{~mol}^{-1}$ (corresponding to $\kappa_{\mathrm{ORG}}$ of 0.10 ) was obtained. A sensitivity analysis showed that the predicted activation curves were reproducible for up to a $25 \%$ change in the optimized value of $V_{\mathrm{m} \text {,ORG }}$ (cf. Supplementary Material in King et al., 2007); for $\kappa_{\mathrm{ORG}}$ the corresponding change was \pm 0.03 . The obtained $V_{\mathrm{m}, \mathrm{ORG}}$ for the secondary organic material formed by isoprene photooxidation can be compared to $V_{\mathrm{m}, \mathrm{ORG}}$ values of 145,148 , and $180 \mathrm{~cm}^{3} \mathrm{~mol}^{-1}$ previously reported by Hartz et al. (2005), King et al. (2009), and Engelhart et al. (2008), respectively, for the organic material formed by the dark ozonolysis of monoterpenes. The obtained $\kappa_{\mathrm{ORG}}$ can be compared to the results of Prenni et al. (2007), Duplissy et al. (2008), Engelhart et al. (2008), and Wex et al. (2009). Those studies, representing the (photo)oxidation of monoterpenes as well as small aromatic molecules, found that $\kappa_{\mathrm{ORG}}$ ranged between 0.10 and 0.18 with uncertainties of up to \pm 0.08 . Given the similarity within uncertainty of these $\kappa_{\mathrm{ORG}}$, the $\mathrm{CCN}$ activity of secondary organic material produced by the photooxidation of isoprene and that resulting from other investigated precursor gases can be considered equivalent.

The secondary organic material for the experiments summarized in Table 1 was characterized by on-line particle mass spectrometry (Canagaratna et al., 2007). King et al. (2009)

\footnotetext{
${ }^{1} \mathrm{An}$ improvement in the present implementation is that multiply charged particles are directly accounted for using the numberdiameter distributions measured by $\mathrm{SMPS}_{2}$, supplanting the need for modeling the distribution that passes $\mathrm{DMA}_{2}$.
} 


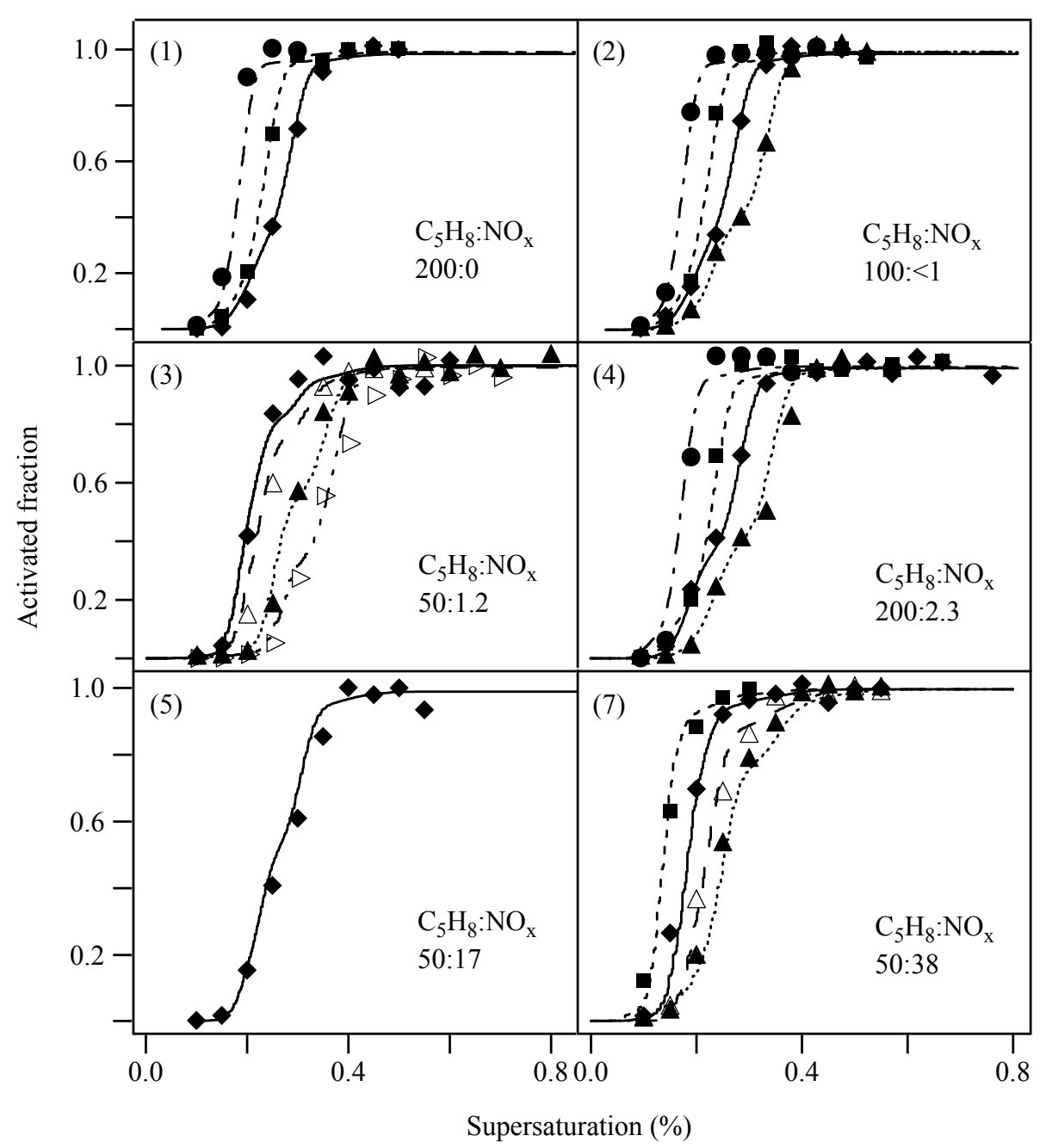

Fig. 3. Observed and modeled CCN activation curves for the experiments described in Table 1 at a thermodenuder setting of $25^{\circ} \mathrm{C}$. In each panel, the initial isoprene concentration (ppbv) prior to reaction and the steady-state $\mathrm{NO}_{\mathrm{x}}$ concentration (ppbv) during reaction are indicated as ratios. The particle mode diameters selected by $\mathrm{DMA}_{2}$ for measurement of their activation curves include $70 \mathrm{~nm}(\triangleright ;$ dashed double-dotted line), $80 \mathrm{~nm}(\boldsymbol{\Delta}$; dotted line), $90 \mathrm{~nm}(\triangle$; long-dashed line), $100 \mathrm{~nm}(\boldsymbol{\bullet}$; solid line), $120 \mathrm{~nm}(\boldsymbol{\square}$; short-dashed line), and $150 \mathrm{~nm}(\bullet ;$ dashed dotted line). The shown data points represent averages across several hours.

showed that, in the case of the dark ozonolysis of $\alpha$-pinene, the CCN activity abruptly increased as the percent contribution of signal intensity at $\mathrm{m} / \mathrm{z} 44$ to the total organic signal intensity passed a threshold at $11 \%$. This result was plausibly explained by a decrease in surface tension caused by an enrichment of carboxylic acids because fragments contributing at $m / z \quad 44$ included $\mathrm{CO}_{2}^{+}$derived from carboxylic acids. For comparison, in the case of isoprene photooxidation as summarized in Table 1, mass spectral characterization of the particle-phase secondary organic material showed that the percent contribution of signal intensity at $\mathrm{m} / \mathrm{z} 44$ varied between $6 \%$ and $9 \%$, with the fraction contributed to $\mathrm{m} / \mathrm{z} 44$ by $\mathrm{CO}_{2}^{+}$varying between $83 \%$ and $89 \%$. The $\mathrm{CCN}$ activity of this material had no detectable variation, so the implication is that the variance in chemical composition reflected by the $6 \%$ to $9 \%$ contribution at $\mathrm{m} / \mathrm{z}, 44$ was insufficient to affect $\mathrm{CCN}$ activation. This implication is consistent with the results for the oxidation products of $\alpha$-pinene that an $11 \%$ threshold value was necessary to influence CCN activity (King et al., 2009; Shilling et al., 2009). In the present experiments for variable $\mathrm{NO}_{\mathrm{x}}$ concentrations, organic nitrates were another potential hygroscopic moiety, but the high-resolution particle mass spectra indicate that these species were insignificant across the range of investigated experimental conditions (Q. Chen and S. T. Martin, personal communication, 2010).

Even though the physicochemical properties describing $\mathrm{CCN}$ activity and chemical composition were invariant for a thermodenuder setting of $25^{\circ} \mathrm{C}$, the organic particle mass concentrations nevertheless depended on the $\mathrm{C}_{5} \mathrm{H}_{8}$ and $\mathrm{NO}_{\mathrm{x}}$ concentrations as well as their ratio (Table 1). The complex 
Table 2. Physical and chemical parameters describing the $\mathrm{CCN}$ activation curves shown in Fig. 3 for a thermodenuder setting of $25^{\circ} \mathrm{C}$. The parameters are invariant at $25^{\circ} \mathrm{C}$ for the investigated range of $\mathrm{C}_{5} \mathrm{H}_{8}: \mathrm{NO}_{\mathrm{x}}$ values.

\begin{tabular}{lcl}
\hline Parameter & Value & Unit \\
\hline Surface tension, $\sigma$ & 0.0725 & $\mathrm{~N} \mathrm{~m}^{-1}$ \\
Molar volume, $V_{\mathrm{m}, \mathrm{AS}}$ & 74.66 & $\mathrm{~cm}^{3} \mathrm{~mol}^{-1}$ \\
van't Hoff factor of $\left(\mathrm{NH}_{4}\right)_{2} \mathrm{SO}_{4}, i_{\mathrm{AS}}$ & 2.2 & \\
Soluble fraction of $\left(\mathrm{NH}_{4}\right)_{2} \mathrm{SO}_{4}, \omega_{\mathrm{AS}}$ & 1 & \\
Effective van't Hoff factor, $i_{\mathrm{ORG}}$ & 1 & \\
Effective molar volume, $V_{\mathrm{m}, \mathrm{ORG}}$ & 180 & $\mathrm{~cm}^{3} \mathrm{~mol}^{-1}$ \\
Effective soluble fraction, $\omega_{\mathrm{ORG}}$ & 1 & \\
Hygroscopicity parameter*,$\kappa_{\mathrm{AS}}$ & 0.53 & \\
Hygroscopicity parameter*,$\kappa_{\mathrm{ORG}}$ & 0.10 & \\
\hline
\end{tabular}

* Simultaneous solution of Eqs. (1) and (2) shows that $\kappa_{\mathrm{k}}=\omega_{\mathrm{k}} i_{\mathrm{k}} V_{\mathrm{m}, \mathrm{k}}^{-1} V_{\mathrm{m}, \mathrm{w}}$.

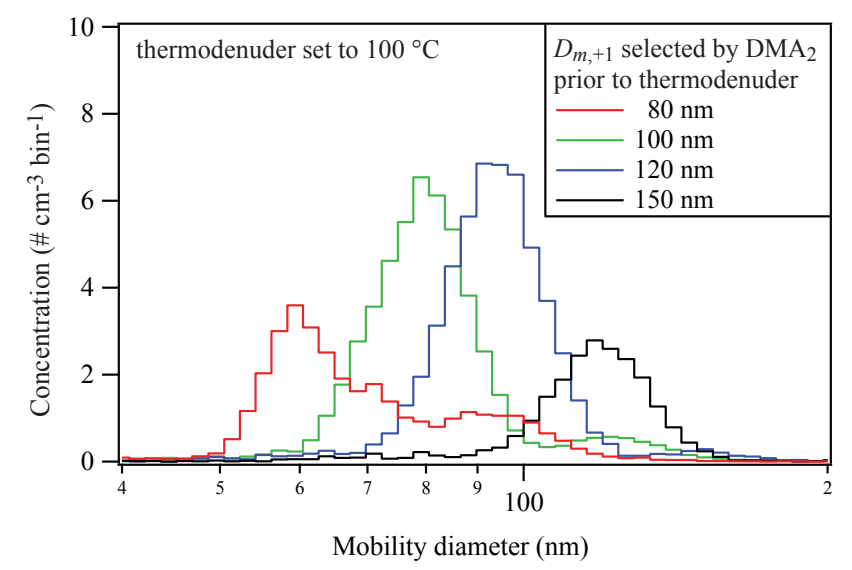

Fig. 4. Number-diameter distributions $\left(\# \mathrm{~cm}^{-3} \mathrm{bin}^{-1}\right)$ measured by $\mathrm{SMPS}_{2}$ for Experiment 2 after particles have passed through the thermodenuder at $100{ }^{\circ} \mathrm{C}$. Mode diameters shown in the legend correspond to the mobility diameters $(+1$ charge equivalent) selected by $\mathrm{DMA}_{2}$ prior to evaporation in the thermodenuder.

dependence of concentration and yield on the $\mathrm{C}_{5} \mathrm{H}_{8}: \mathrm{NO}_{\mathrm{x}}$ ratio and other conditions (e.g., $\mathrm{OH}$ concentration) is discussed by Kroll et al. (2006) and Carlton et al. (2009). The mass yields from this study (viz. $0.4-3.1 \%$ uncorrected for wall loss) agree with those reported in previous studies (cf. Fig. 3 in Carlton et al., 2009). Analysis of the entries in Table 1 shows that there was no obvious relationship between the percent contribution by $\mathrm{m} / \mathrm{z}, 44$ and possible predictive factors, such as the organic particle mass concentration, the organic particle mass yield, the $\mathrm{C}_{5} \mathrm{H}_{8}: \mathrm{NO}_{\mathrm{x}}$ ratio, or the $\mathrm{NO}_{\mathrm{x}}$ concentration. The absence of simple correlations might be explainable by the complex, shifting dominance between the peroxy and nitrate reaction pathways (Carlton et al., 2009).

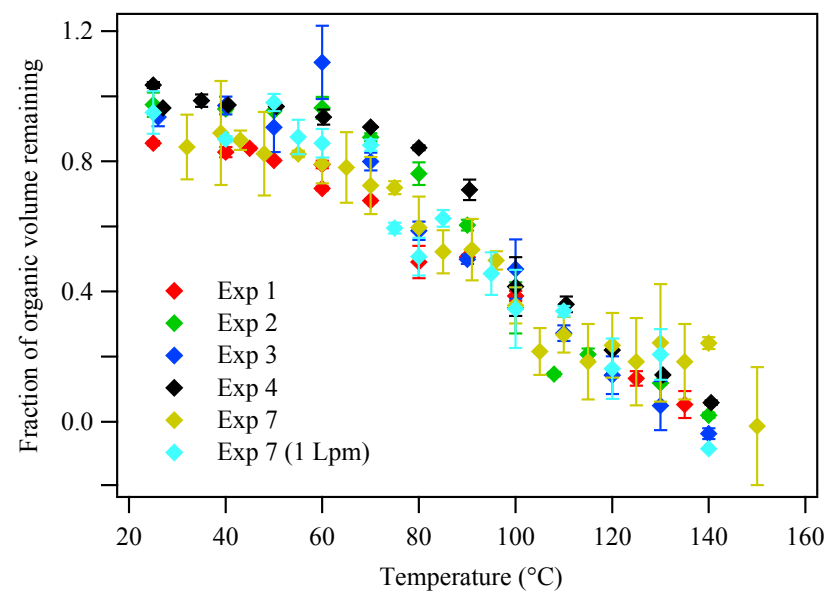

Fig. 5. Residual organic volume fraction of the organic volume for increasing temperature in the thermodenuder. Data are shown for particles selected with $\mathrm{DMA}_{2}$ set to a $100-\mathrm{nm}$ mobility diameter $(+1$ charge equivalent). Organic volume is calculated from the measurements of $\mathrm{SMPS}_{2}$ (e.g., Fig. 4), including compensation for the sulfate core.

The CCN activity of particles after passing through the thermodenuder at 60 and $100{ }^{\circ} \mathrm{C}$ was studied. The numberdiameter distributions shown in Fig. 4 after exposure to $100^{\circ} \mathrm{C}$ can be compared to those shown in Fig. 2 for $25^{\circ} \mathrm{C}$, revealing a shift to smaller diameters because of the evaporation of organic material. Ammonium sulfate did not evaporate for the employed temperatures and residence times (Fig. S1: http://www.atmos-chem-phys.net/10/3953/2010/ acp-10-3953-2010-supplement.pdf) (An et al., 2007; Huffman et al., 2008). Figure 5 shows the residual organic volume fraction for particles initially of $100 \mathrm{~nm}$ for increasing thermodenuder temperature (i.e., volatilization curves). Data from many experiments are shown together in Fig. 5, and within uncertainty the volatilization curves are the same, indicating little to no dependence on the extent of evaporation for the different $\mathrm{C}_{5} \mathrm{H}_{8}: \mathrm{NO}_{\mathrm{x}}$ ratios among the experiments. The results at $100{ }^{\circ} \mathrm{C}$ agree with those of Poulain et al. (2009), who also observed that $65 \%$ of the organic particle mass concentration formed from $\alpha$-pinene ozonolysis evaporated at $100^{\circ} \mathrm{C}$. Fierz et al. (2007) emphasized the importance of the effects of thermodenuder residence time, and we therefore carried out experiments both for flow rates of 2.5 and $1 \mathrm{Lpm}$, corresponding to residence times of 0.7 and $1.8 \mathrm{~s}$, respectively. Similar volatilization curves were obtained for both flow rates. No particle mass spectra were collected after the thermodenuder.

CCN activation curves were collected for increasing thermodenuder temperature (Fig. S2: http://www.atmos-chem-phys.net/10/3953/2010/ acp-10-3953-2010-supplement.pdf). The shift in numberdiameter distribution to smaller particles for increasing thermodenuder treatment (cf. Fig. 4) is expected to shift 


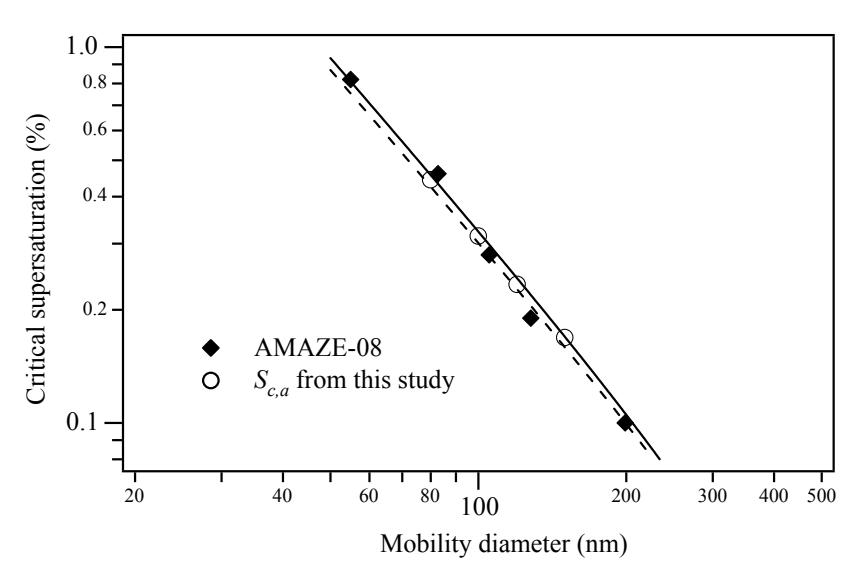

Fig. 6. Size-resolved critical supersaturations measured during AMAZE-08 (diamonds) compared to apparent critical supersaturations $S_{\mathrm{c}, \mathrm{a}}$ that can be predicted using the results of the present study (open circles). The predictions use Eq. (1) and the parameters of Table 2. The linear fit of all $S_{\mathrm{c}, \mathrm{a}}$ is shown as the solid line. The dashed

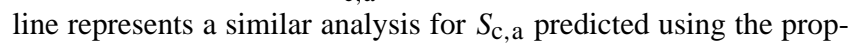
erties of secondary organic material formed by the dark ozonolysis of $\alpha$-pinene (dashed line) (King et al., 2007, 2009).

the activation curves to higher supersaturations. However, for experiments with larger $\mathrm{C}_{5} \mathrm{H}_{8}: \mathrm{NO}_{\mathrm{x}}$ ratios, the observed $\mathrm{CCN}$ curves were shifted even higher than expected from diameter decreases, indicating a decrease in the intrinsic $\mathrm{CCN}$ activation properties of the organic component of the particles (i.e., a decrease of $\kappa_{\mathrm{ORG}}$ ) for increasing thermodenuder temperature. Chemical changes in the organic component can result from the preferential evaporative loss of more-volatile molecules, leaving a residuum of less-volatile molecules (i.e., a process akin to fractional distillation). Meyer et al. (2009) and Poulain et al. (2009) reported that the less-volatile fraction of $\alpha$-pinene SOA was also the less-hygroscopic fraction. Poulain et al. monitored compositional changes in the particles following thermodenuder treatment and found that the concentration of oxygenated compounds (which are expected to be more hygroscopic) decreased at $100^{\circ} \mathrm{C}$. Kalberer et al. (2004), El Haddad et al. (2009), Shapiro et al. (2009), and references therein have shown that high temperatures can induce chemical reactions, such as the decomposition of peroxides, the oligomerization of alcohols with carbonyls by aldol condensation, or the esterification of alcohols with carboxylic acids, all largely driven by the elimination of molecular water. Oligomerization in particular increases molar volume $V_{\mathrm{m}, \mathrm{k}}$ and thus decreases $\kappa_{\mathrm{ORG}}$ according to $\kappa_{\mathrm{k}}=\omega_{\mathrm{k}} i_{\mathrm{k}} V_{\mathrm{m}, \mathrm{k}}^{-1} V_{\mathrm{m}, \mathrm{w}}$. Significant oligomerization could also decrease the water-soluble fraction $\omega_{\mathrm{k}}$.

To explore the extent of chemical transformation that is required to change the $\mathrm{CCN}$ properties as much as observed, we varied the parameters of Eq. (1) to fit the experimental data. For Experiment 1 with treatment at $100^{\circ} \mathrm{C}$, changes to
$V_{\mathrm{m}, \mathrm{ORG}}>10^{4} \mathrm{~cm}^{3} \mathrm{~mol}^{-1}, i_{\mathrm{ORG}}$ less than 0.02 , or $\sigma$ greater than $0.085 \mathrm{~N} \mathrm{~m}^{-1}$ can bring closure between the model and data. An increase in the surface tension to $0.085 \mathrm{~N} \mathrm{~m}^{-1}$ is counter to evidence that the organic material, if anything, depresses surface tension (Facchini et al., 1999). Similarly, van't Hoff factors of $<0.02$ are not congruent with those of water-soluble organic molecules, which are generally not much smaller than unity, both for small molecules as well as for macromolecules (Mikhailov et al., 2004, 2009). An effective molar volume of $>10^{4} \mathrm{~cm}^{3} \mathrm{~mol}^{-1}$ might be explained by the formation of oligomers having molecular mass greater than $10 \mathrm{kDa}$, but the kinetics must be very rapid, requiring the formation of 100-mers during the exposure times in the thermodenuder. This possibility cannot be fully ruled out.

Alternatively, the observations can be explained by a decrease of the soluble fraction $\omega_{\mathrm{ORG}}^{*}$ upon heating. Such a decrease could arise in part from the evaporation of soluble species and in part from the formation of $n$-mers. This case differentiates from the one discussed above because the soluble fraction decreases beginning with dimers, trimers, and tetramers, i.e., for $n \ll 100$. The activation curves of Experiment 1 at 60 and $100^{\circ} \mathrm{C}$ can be modeled with the parameters of Table 2 unchanged except for $\omega_{\mathrm{ORG}}=0.6$ and $\omega_{\mathrm{ORG}}=0.02$, respectively. In this way, possible co-changes in $V_{\mathrm{m}, \mathrm{ORG}}, i_{\mathrm{ORG}}$, or $\sigma$, which we cannot resolve in our analysis, are gathered into an effective change in $\omega_{\mathrm{ORG}}$ (Engelhart et al., 2008). In view of the relatively low molecular mass and high polarity of the gas-phase oxidation products of isoprene, water-soluble material is expected in the particle phase. Oligomerization in the particle phase, however, can lead to products of reduced water solubility. Thus, we suggest that the chemical suppression of CCN activity observed upon heating of the isoprene SOA particles is explained by oligomerization in the condensed phase.

A case study applied to AMAZE-08. The results of this study can be compared to field observations reported by Gunthe et al. (2009) as part of the Amazonian Aerosol Characterization Experiment (AMAZE-08) that took place during the wet season in the central Amazon Basin. The site is located such that air masses travel mainly from the northeast over $1600 \mathrm{~km}$ of rainforest. Isoprene concentrations approach 10 ppbv at midday (Karl et al., 2007), $\mathrm{NO}_{\mathrm{x}}$ concentrations are typically significantly less than $1 \mathrm{ppbv}$ during the wet season (Andreae et al., 2002; Trebs et al., 2006), submicron particle organic mass concentrations are around $1 \mu \mathrm{g} \mathrm{m}^{-3}$, and the particles are dominantly composed of sulfate and organic materials without nitrate or soot common to anthropogenically affected regions of the world (Martin et al., 2010). Chen et al. (2009) concluded that most of the organic material composing submicron particles over the Amazon Basin during AMAZE-08 was derived from biogenic SOA production. The conditions of the experiments summarized in Table 1 for the Harvard Environmental Chamber therefore have important commonalities with those prevailing in the Amazon Basin. 
To facilitate comparisons of complex data sets, we define an apparent critical supersaturation $S_{\mathrm{c}, \mathrm{a}}$. This value is calculated for one geometric diameter and one organic volume fraction (i.e., effectively assuming homogeneity within a population) using Eq. (1) and the physicochemical properties of Table 2. In our analysis, the organic volume fraction is based on the measurements in AMAZE-08 at each analyzed diameter (Gunthe et al., 2009). The average organic fractions were greater than 0.8 , and Gunthe et al. showed that a mixing rule to obtain an overall $\kappa$ value based on individual $\kappa$ values and volume fractions of the sulfate and organic components (using $\kappa=0.1$ for the organic material on the basis of the widespread dominance of secondary organic components in the Amazon Basin) could explain well the variability observed in $\mathrm{CCN}$ activity during the field observations. This finding suggested to us that results on $\mathrm{CCN}$ activity recorded in the Harvard Environmental Chamber for mixed sulfateorganic particles should also be germane to the Amazon.

Figure 6 shows $S_{\mathrm{c}, \mathrm{a}}$ for $D_{\mathrm{m},+1}$ of $80,100,120$, and $150 \mathrm{~nm}$. Data from AMAZE-08 are also included in Fig. 6; the shown points represent campaign averages. For further comparison, $S_{\mathrm{c}, \mathrm{a}}$ is also calculated by Eq. (1) and using the physicochemical parameters measured previously for the secondary organic material resulting from the oxidation of $\alpha$-pinene (King et al., 2007). Figure 6 shows that predictions based on organic-component parameters derived from SOA production by the oxidation of either (or both) isoprene and $\alpha$-pinene agree well with the AMAZE-08 observations. These findings suggest that the CCN activity of aerosol particles over regions and at times for which the particle components are dominated by the oxidation products of biogenic sulfur and organic emissions can be accurately modeled using a simple two-component Köhler model that assumes full solubility and $\kappa_{\mathrm{ORG}}=0.1$. Furthermore, the chamber studies cited earlier also suggest that secondary organic components produced from the oxidation of anthropogenic precursor gases also have $\kappa_{\mathrm{ORG}}=0.1$ in regard to $\mathrm{CCN}$ activity. This value should therefore be widely representative and applicable for use in large-scale atmospheric and climate model studies. This conclusion is supported not only by $\mathrm{CCN}$ field measurements in pristine rainforest air of Amazonia (Gunthe et al., 2009) but also by field experiments in polluted urban and rural air in central Europe (Dusek et al., 2010).

\section{Conclusions}

The CCN activity of mixed organic-sulfate particles produced by the condensation of the reaction products of the hydroxyl-radical-initiated photooxidation of isoprene was studied. Over the range of investigated $\mathrm{C}_{5} \mathrm{H}_{8}: \mathrm{NO}_{\mathrm{x}}$ ratios, the CCN activation curves were successfully predicted using a simple two-component Köhler model and a single suite of physicochemical parameters for fully water-soluble secondary organic material. Experimental conditions and pa- rameter values are summarized in Tables 1 and 2, respectively. The values of the parameters are similar to those reported in the literature for organic material produced by the oxidation of other VOC precursor gases, such as monoterpenes and small aromatic molecules. These findings suggest that over Amazonia and other regions dominated by high biogenic emissions, the $\mathrm{CCN}$ activity of particles (as represented in large-scale atmospheric and climate models) can be simply and accurately predicted using a multi-component Köhler model that employs a single suite of parameters for biogenic secondary organic components in conjunction with the parameters representing the inorganic species.

Acknowledgements. This material is based upon work supported by the Office of Science (BES), US Department of Energy, Grant No. DE-FG02-08ER64529. SMK acknowledges support from the EPA STAR fellowship program and from the Harvard University DRCLAS Jorge Paulo Lemann Fellowship. TR acknowledges support from the Danish Agency for Science Technology and Innovation under Grant No. 272-06-0318. QC acknowledges support from the NASA Earth and Space Science Fellowship. JES acknowledges support from the ACI. The authors thank J. Kroll for helpful discussion.

Edited by: O. Möhler

\section{References}

An, W. J., Pathak, R. K., Lee, B. H., and Pandis, S. N.: Aerosol volatility measurement using an improved thermodenuder: Application to secondary organic aerosol, J. Aerosol. Sci., 38, 305314, 2007.

Andreae, M. O. and Crutzen, P. J.: Atmospheric aerosols: Biogeochemical sources and role in atmospheric chemistry, Science, 276, 1052-1058, 1997.

Andreae, M. O., Artaxo, P., Brandao, C., Carswell, F. E., Ciccioli, P., da Costa, A. L., Culf, A. D., Esteves, J. L., Gash, J. H. C., Grace, J., Kabat, P., Lelieveld, J., Malhi, Y., Manzi, A. O., Meixner, F. X., Nobre, A. D., Nobre, C., Ruivo, M. A., Silva-Dias, M. A., Stefani, P., Valentini, R., von Jouanne, J., and Waterloo, M. J.: Biogeochemical cycling of carbon, water, energy, trace gases, and aerosols in Amazonia: The LBA-EUSTACH experiments, J. Geophys. Res., 107, 8066, doi:8010.1029/2001JD000524, 2002.

Andreae, M. O. and Rosenfeld, D.: Aerosol-cloud-precipitation interactions, Part 1: The nature and sources of cloud-active aerosols, Earth-Sci. Rev., 89, 13-41, 2008.

Bilde, M. and Svenningsson, B.: CCN activation of slightly soluble organics: The importance of small amounts of inorganic salt and particle phase, Tellus, 56, 128-134, 2004.

Brechtel, F. J. and Kreidenweis, S. M.: Predicting particle critical supersaturation from hygroscopic growth measurements in the humidified TDMA, Part I: Theory and sensitivity studies, J. Atmos. Sci., 57, 1854-1871, 2000.

Canagaratna, M. R., Jayne, J. T., Jimenez, J. L., Allan, J. D., Alfarra, M. R., Zhang, Q., Onasch, T., Drewnick, F., Coe, H., Middlebrook, A. M., Delia, A., Williams, L. R., Trimborn, A. M., Northway, M. J., DeCarlo, P. F., Kolb, C. E., Davidovits, P., and 
Worsnop, D. R.: Chemical and microphysical characterization of ambient aerosol with the Aerodyne aerosol mass spectrometer, Mass. Spectrom. Rev., 26, 185-222, 2007.

Carlton, A. G., Wiedinmyer, C., and Kroll, J. H.: A review of secondary Organic Aerosol (SOA) formation from isoprene, Atmos. Chem. Phys., 9, 4987-5005, 2009,

http://www.atmos-chem-phys.net/9/4987/2009/.

Chen, Q., Farmer, D. K., Schneider, J., Zorn, S. R., Heald, C. L., Karl, T. G., Guenther, A., Allan, J. D., Robinson, N., Coe, H., Kimmel, J. R., Pauliquevis, T., Borrmann, S., Pöschl, U., Andreae, M. O., Artaxo, P., Jimenez, J. L., and Martin, S. T.: Mass spectral characterization of submicron biogenic organic particles in the Amazon Basin, Geophys. Res. Lett., 36, L20806, doi:20810.21029/22009GL039880, 2009.

Chung, S. H. and Seinfeld, J. H.: Global distribution and climate forcing of carbonaceous aerosols, J. Geophys. Res., 107, 4407, doi:4410.1029/2001JD001397, 2002.

Claeys, M., Graham, B., Vas, G., Wang, W., Vermeylen, R., Pashynska, V., Cafmeyer, J., Guyon, P., Andreae, M. O., Artaxo, P., and Maenhaut, W.: Formation of secondary organic aerosols through photooxidation of isoprene, Science, 303, 1173-1176, 2004.

Cruz, C. N. and Pandis, S. N.: The effect of organic coatings on the cloud condensation nuclei activation of inorganic atmospheric aerosol, J. Geophys. Res., 103, 13111-13123, 1998.

Dommen, J., Metzger, A., Duplissy, J., Kalberer, M., Alfarra, M. R., Gascho, A., Weingartner, E., Prevot, A. S. H., Verheggen, B., and Baltensperger, U.: Laboratory observation of oligomers in the aerosol from isoprene/ $\mathrm{NO}_{\mathrm{x}}$ photooxidation, Geophys. Res. Lett., 33, L13805, doi:13810.11029/12006GL026523, 2006.

Duplissy, J., Gysel, M., Alfarra, M. R., Dommen, J., Metzger, A., Prevot, A. S. H., Weingartner, E., Laaksonen, A., Raatikainen, T., Good, N., Turner, S. F., McFiggans, G., and Baltensperger, U.: Cloud forming potential of secondary organic aerosol under near atmospheric conditions, Geophys. Res. Lett., 35, L03818, doi:03810.01029/02007GL031075, 2008.

Dusek, U., Frank, G. P., Curtius, J., Drewnick, F., Schneider, J., Kürten, A., Rose, D., Andreae, M. O., Borrmann, S., and Pöschl, U.: Enhanced organic mass fraction and decreased hygroscopicity of cloud condensation nuclei $(\mathrm{CCN})$ during new particle formation events, Geophys. Res. Lett., 37, L03804, doi:03810.01029/02009GL040930, 2010.

Edney, E. O., Kleindienst, T. E., Jaoui, M., Lewandowski, M., Offenberg, J. H., Wang, W., and Claeys, M.: Formation of 2-methyl tetrols and 2-methylglyceric acid in secondary organic aerosol from laboratory irradiated isoprene/ $\mathrm{NO}_{\mathrm{x}} / \mathrm{SO}_{2}$ /air mixtures and their detection in ambient $\mathrm{PM}_{2.5}$ samples collected in the eastern United States, Atmos. Environ., 39, 5281-5289, 2005.

El Haddad, I., Yao Liu, Nieto-Gligorovski, L., Michaud, V., Temime-Roussel, B., Quivet, E., Marchand, N., Sellegri, K., and Monod, A.: In-cloud processes of methacrolein under simulated conditions - Part 2: Formation of secondary organic aerosol, Atmos. Chem. Phys., 9, 5107-5117, 2009,

http://www.atmos-chem-phys.net/9/5107/2009/.

Engelhart, G. J., Asa-Awuku, A., Nenes, A., and Pandis, S. N.: CCN activity and droplet growth kinetics of fresh and aged monoterpene secondary organic aerosol, Atmos. Chem. Phys., 8, 3937-3949, 2008,

http://www.atmos-chem-phys.net/8/3937/2008/.

Facchini, M. C., Mircea, M., Fuzzi, S., and Charlson, R. J.: Cloud albedo enhancement by surface-active organic solutes in growing droplets, Nature, 401, 257-259, 1999.

Fierz, M., Vernooij, M. G. C., and Burtscher, H.: An improved lowflow thermodenuder, J. Aerosol. Sci., 38, 1163-1168, 2007.

Goldstein, A. H. and Galbally, I. E.: Known and unexplored organic constituents in the earth's atmosphere, Environ. Sci. Technol., 41, 1514-1521, 2007.

Griffin, R. J., Cocker, D. R., Flagan, R. C., and Seinfeld, J. H.: Organic aerosol formation from the oxidation of biogenic hydrocarbons, J. Geophys. Res., 104, 3555-3567, 1999.

Guenther, A., Karl, T., Harley, P., Wiedinmyer, C., Palmer, P. I., and Geron, C.: Estimates of global terrestrial isoprene emissions using MEGAN (Model of Emissions of Gases and Aerosols from Nature), Atmos. Chem. Phys., 6, 3181-3210, 2006,

http://www.atmos-chem-phys.net/6/3181/2006/.

Gunthe, S. S., King, S. M., Rose, D., Chen, Q., Roldin, P., Farmer, D. K., Jimenez, J. L., Artaxo, P., Andreae, M. O., Martin, S. T., and Pöschl, U.: Cloud condensation nuclei in pristine tropical rainforest air of Amazonia: size-resolved measurements and modeling of atmospheric aerosol composition and CCN activity, Atmos. Chem. Phys., 9, 7551-7575, 2009,

http://www.atmos-chem-phys.net/9/7551/2009/.

Henze, D. K. and Seinfeld, J. H.: Global secondary organic aerosol formation from isoprene oxidation, Geophys. Res. Lett., 33, L09812, doi:10.01029/02006GL025976, 2006.

Huffman, J. A., Ziemann, P. J., Jayne, J. T., Worsnop, D. R., and Jimenez, J. L.: Development and characterization of a fast-stepping/scanning thermodenuder for chemically-resolved aerosol volatility measurements, Aerosol Sci. Technol., 42, 395407, 2008.

IPCC Fourth Assessment Report: Climate Change 2007: The Physical Science Basis, Cambridge University Press, Cambridge, UK and New York, USA, 996 pp., 2007.

Jonsson, A. M., Hallquist, M., and Saathoff, H.: Volatility of secondary organic aerosols from the ozone initiated oxidation of $\alpha$ pinene and limonene, J. Aerosol. Sci., 38, 843-852, 2007.

Kalberer, M., Paulsen, D., Sax, M., Steinbacher, M., Dommen, J., Prevot, A. S. H., Fisseha, R., Weingartner, E., Frankevich, V., Zenobi, R., and Baltensperger, U.: Identification of polymers as major components of atmospheric organic aerosols, Science, 303, 1659-1662, 2004.

Kanakidou, M., Seinfeld, J. H., Pandis, S. N., Barnes, I., Dentener, F. J., Facchini, M. C., Van Dingenen, R., Ervens, B., Nenes, A., Nielsen, C. J., Swietlicki, E., Putaud, J. P., Balkanski, Y., Fuzzi, S., Horth, J., Moortgat, G. K., Winterhalter, R., Myhre, C. E. L., Tsigaridis, K., Vignati, E., Stephanou, E. G., and Wilson, J.: Organic aerosol and global climate modelling: a review, Atmos. Chem. Phys., 5, 1053-1123, 2005,

http://www.atmos-chem-phys.net/5/1053/2005/.

Karl, T., Guenther, A., Yokelson, R. J., Greenberg, J., Potosnak, M., Blake, D. R., and Artaxo, P.: The tropical forest and fire emissions experiment: Emission, chemistry, and transport of biogenic volatile organic compounds in the lower atmosphere over Amazonia, J. Geophys. Res., 112, D18302, doi:10.1029/2007JD008539, 2007.

King, S. M., Rosenoern, T., Shilling, J. E., Chen, Q., and Martin, S. T.: Cloud condensation nucleus activity of secondary organic aerosol particles mixed with sulfate, Geophys. Res. Lett., 34, L24803, doi:10.21029/22007GL030390, 2007. 
King, S. M., Rosenoern, T., Shilling, J. E., Chen, Q., and Martin, S. T.: Increased cloud activation potential of secondary organic aerosol for atmospheric mass loadings, Atmos. Chem. Phys., 9, 2959-2971, 2009, http://www.atmos-chem-phys.net/9/2959/2009/.

Kleindienst, T. E., Edney, E. O., Lewandowski, M., Offenberg, J. H., and Jaoui, M.: Secondary organic carbon and aerosol yields from the irradiations of isoprene and $\alpha$-pinene in the presence of $\mathrm{NO}_{\mathrm{x}}$ and $\mathrm{SO}_{2}$, Environ. Sci. Technol., 40, 3807-3812, 2006.

Kleindienst, T. E., Lewandowski, M., Offenberg, J. H., Jaoui, M., and Edney, E. O.: Ozone-isoprene reaction: Re-examination of the formation of secondary organic aerosol, Geophys. Res. Lett., 34, L01805, doi:10.01029/02006GL027485, 2007.

Kroll, J. H., Ng, N. L., Murphy, S. M., Flagan, R. C., and Seinfeld, J. H.: Secondary organic aerosol formation from isoprene photooxidation, Environ. Sci. Technol., 40, 1869-1877, 2006.

Kulmala, M., Laaksonen, A., Charlson, R. J., and Korhonen, P.: Clouds without supersaturation, Nature, 388, 336-337, 1997.

Laaksonen, A., Korhonen, P., Kulmala, M., and Charlson, R. J.: Modification of the Köhler equation to include soluble trace gases and slightly soluble substances, J. Atmos. Sci., 55, 853862,1998

Lance, S., Medina, J., Smith, J. N., and Nenes, A.: Mapping the operation of the DMT Continuous Flow CCN counter, Aerosol Sci. Technol., 40, 242-254, 2006.

Lei, W., Zhang, R., McGivern, W. S., Derecskei-Kovacs, A., and North, S. W.: Theoretical study of isomeric branching in the isoprene-OH reaction: implications to final product yields in isoprene oxidation, Chem. Phys. Lett., 326, 109-114, 2000.

Lim, H. J., Carlton, A. G., and Turpin, B. J.: Isoprene forms secondary organic aerosol through cloud processing: model simulations, Environ. Sci. Technol., 39, 4441-4446, 2005.

Lohmann, U. and Feichter, J.: Global indirect aerosol effects: a review, Atmos. Chem. Phys., 5, 715-737, 2005, http://www.atmos-chem-phys.net/5/715/2005/.

Martin, S. T., Andreae, M. O., Artaxo, P., Baumgardner, D., Chen, Q., Goldstein, A. H., Guenther, A., Heald, C. L., Mayol-Bracero, O. L., McMurry, P. H., Pauliquevis, T., Poeschl, U., Prather, K. A., Roberts, G. C., Saleska, S. R., Dias, M. A. S., Spracklen, D. V., Swietlicki, E., and Trebs, I.: Sources and properties of Amazonian aerosol particles, Rev. Geophys., 48, RG2002, doi:10.1029/2008RG000280, 2010.

McFiggans, G., Artaxo, P., Baltensperger, U., Coe, H., Facchini, M. C., Feingold, G., Fuzzi, S., Gysel, M., Laaksonen, A., Lohmann, U., Mentel, T. F., Murphy, D. M., O’Dowd, C. D., Snider, J. R., and Weingartner, E.: The effect of physical and chemical aerosol properties on warm cloud droplet activation, Atmos. Chem. Phys., 6, 2593-2649, 2006,

http://www.atmos-chem-phys.net/6/2593/2006/.

Meyer, N. K., Duplissy, J., Gysel, M., Metzger, A., Dommen, J., Weingartner, E., Alfarra, M. R., Prevot, A. S. H., Fletcher, C., Good, N., McFiggans, G., Jonsson, Å. M., Hallquist, M., Baltensperger, U., and Ristovski, Z. D.: Analysis of the hygroscopic and volatile properties of ammonium sulphate seeded and unseeded SOA particles, Atmos. Chem. Phys., 9, 721-732, 2009, http://www.atmos-chem-phys.net/9/721/2009/.

Mikhailov, E., Vlasenko, S., Niessner, R., and Pöschl, U.: Interaction of aerosol particles composed of protein and saltswith water vapor: hygroscopic growth and microstructural rearrangement,
Atmos. Chem. Phys., 4, 323-350, 2004,

http://www.atmos-chem-phys.net/4/323/2004/.

Mikhailov, E., Vlasenko, S., Martin, S. T., Koop, T., and Pöschl, U.: Amorphous and crystalline aerosol particles interacting with water vapor: conceptual framework and experimental evidence for restructuring, phase transitions and kinetic limitations, Atmos. Chem. Phys., 9, 9491-9522, 2009,

http://www.atmos-chem-phys.net/9/9491/2009/.

Murphy, D. M., Cziczo, D. J., Froyd, K. D., Hudson, P. K., Matthew, B. M., Middlebrook, A. M., Peltier, R. E., Sullivan, A., Thomson, D. S., and Weber, R. J.: Single-particle mass spectrometry of tropospheric aerosol particles, J. Geophys. Res., 111, D23S32, doi:10.1029/2006JD007340, 2006.

Ng, N. L., Kwan, A. J., Surratt, J. D., Chan, A. W. H., Chhabra, P. S., Sorooshian, A., Pye, H. O. T., Crounse, J. D., Wennberg, P. O., Flagan, R. C., and Seinfeld, J. H.: Secondary organic aerosol (SOA) formation from reaction of isoprene with nitrate radicals $\left(\mathrm{NO}_{3}\right)$, Atmos. Chem. Phys., 8, 4117-4140, 2008 , http://www.atmos-chem-phys.net/8/4117/2008/.

Paulsen, D., Weingartner, E., Alfarra, M. R., and Baltensperger, U.: Volatility measurements of photochemically and nebulizergenerated organic aerosol particles, J. Aerosol. Sci., 37, 10251051, 2006.

Petters, M. D. and Kreidenweis, S. M.: A single parameter representation of hygroscopic growth and cloud condensation nucleus activity, Atmos. Chem. Phys., 7, 1961-1971, 2007, http://www.atmos-chem-phys.net/7/1961/2007/.

Poulain, L., Wu, Z., Petters, M. D., Wex, H., Hallbauer, E., Wehner, B., Massling, A., Kreidenweis, S. M., and Stratmann, F.: Towards closing the gap between hygroscopic growth and $\mathrm{CCN}$ activation for secondary organic aerosols - Part 3: Influence of the chemical composition on the hygroscopic properties and volatile fractions of aerosols, Atmos. Chem. Phys. Discuss., 9, 1668316714, 2009, http://www.atmos-chem-phys-discuss.net/9/16683/2009/.

Prenni, A. J., Petters, M. D., Kreidenweis, S. M., and DeMott, P. J.: Cloud droplet activation of secondary organic aerosol, J. Geophys. Res., 112, D10223, doi:10.11029/12006JD007963, 2007.

Presto, A. A., Hartz, K. E. H., and Donahue, N. M.: Secondary organic aerosol production from terpene ozonolysis. 2. Effect of $\mathrm{NO}_{\mathrm{x}}$ concentration, Environ. Sci. Technol., 39, 7046-7054, 2005.

Roberts, G. C. and Nenes, A.: A continuous-flow streamwise thermal-gradient $\mathrm{CCN}$ chamber for atmospheric measurements, Aerosol Sci. Technol., 39, 206-221, 2005.

Rose, D., Gunthe, S. S., Mikhailov, E., Frank, G. P., Dusek, U., Andreae, M. O., and Pöschl, U.: Calibration and measurement uncertainties of a continuous-flow cloud condensation nuclei counter (DMT-CCNC): $\mathrm{CCN}$ activation of ammonium sulfate and sodium chloride aerosol particles in theory and experiment, Atmos. Chem. Phys., 8, 1153-1179, 2008, http://www.atmos-chem-phys.net/8/1153/2008/.

Scatchard, G., Kavanagh, G. M., and Ticknor, L. B.: Vapor-liquid equilibrium. VIII. Hydrogen peroxide-water mixtures, J. Am. Chem. Soc., 74, 3715-3720, doi:10.1021/ja01135a001, 1952.

Seinfeld, J. H. and Pandis, S. N.: Atmospheric Chemistry and Physics: From Air Pollution to Climate Change, WileyInterscience, New York, USA, 2006.

Shapiro, E. L., Szprengiel, J., Sareen, N., Jen, C. N., Giordano, 
M. R., and McNeill, V. F.: Light-absorbing secondary organic material formed by glyoxal in aqueous aerosol mimics, Atmos. Chem. Phys., 9, 2289-2300, 2009, http://www.atmos-chem-phys.net/9/2289/2009/.

Shilling, J. E., King, S. M., Mochida, M., Worsnop, D. R., and Martin, S. T.: Mass spectral evidence that small changes in composition caused by oxidative aging processes alter aerosol CCN properties, J. Phys. Chem. A, 111, 3358-3368, 2007.

Shilling, J. E., Chen, Q., King, S. M., Rosenoern, T., Kroll, J. H., Worsnop, D. R., McKinney, K. A., and Martin, S. T.: Particle mass yield in secondary organic aerosol formed by the dark ozonolysis of $\alpha$-pinene, Atmos. Chem. Phys., 8, 2073-2088, 2008, http://www.atmos-chem-phys.net/8/2073/2008/.

Shilling, J. E., Chen, Q., King, S. M., Rosenoern, T., Kroll, J. H., Worsnop, D. R., DeCarlo, P. F., Aiken, A. C., Sueper, D., Jimenez, J. L., and Martin, S. T.: Loading-dependent elemental composition of $\alpha$-pinene SOA particles, Atmos. Chem. Phys., 9, 771-782, 2009, http://www.atmos-chem-phys.net/9/771/2009/.

Shulman, M. L., Jacobson, M. C., Carlson, R. J., Synovec, R. E., and Young, T. E.: Dissolution behavior and surface tension effects of organic compounds in nucleating cloud droplets, Geophys. Res. Lett., 23, 277-280, 1996.

Stanier, C. O., Pathak, R. K., and Pandis, S. N.: Measurements of the volatility of aerosols from $\alpha$-pinene ozonolysis, Environ. Sci. Technol., 41, 2756-2763, 2007.

Sun, J. M. and Ariya, P. A.: Atmospheric organic and bio-aerosols as cloud condensation nuclei $(\mathrm{CCN})$ : A review, Atmos. Environ., 40, 795-820, 2006.

Trebs, I., Lara, L. L., Zeri, L. M. M., Gatti, L. V., Artaxo, P., Dlugi, R., Slanina, J., Andreae, M. O., and Meixner, F. X.: Dry and wet deposition of inorganic nitrogen compounds to a tropical pasture site (Rondônia, Brazil), Atmos. Chem. Phys., 6, 447-469, 2006, http://www.atmos-chem-phys.net/6/447/2006/.
Tsigaridis, K. and Kanakidou, M.: Global modelling of secondary organic aerosol in the troposphere: a sensitivity analysis, Atmos. Chem. Phys., 3, 1849-1869, 2003, http://www.atmos-chem-phys.net/3/1849/2003/.

Volkamer, R., Ziemann, P. J., and Molina, M. J.: Secondary Organic Aerosol Formation from Acetylene $\left(\mathrm{C}_{2} \mathrm{H}_{2}\right)$ : seed effect on SOA yields due to organic photochemistry in the aerosol aqueous phase, Atmos. Chem. Phys., 9, 1907-1928, 2009, http://www.atmos-chem-phys.net/9/1907/2009/.

Wex, H., Petters, M. D., Carrico, C. M., Hallbauer, E., Massling, A., McMeeking, G. R., Poulain, L., Wu, Z., Kreidenweis, S. M., and Stratmann, F.: Towards closing the gap between hygroscopic growth and activation for secondary organic aerosol: Part 1 Evidence from measurements, Atmos. Chem. Phys., 9, 39873997, 2009, http://www.atmos-chem-phys.net/9/3987/2009/.

Zhang, Q., Jimenez, J. L., Canagaratna, M. R., Allan, J. D., Coe, H., Ulbrich, I., Alfarra, M. R., Takami, A., Middlebrook, A. M., Sun, Y. L., Dzepina, K., Dunlea, E., Docherty, K., DeCarlo, P. F., Salcedo, D., Onasch, T., Jayne, J. T., Miyoshi, T., Shimono, A., Hatakeyama, S., Takegawa, N., Kondo, Y., Schneider, J., Drewnick, F., Borrmann, S., Weimer, S., Demerjian, K., Williams, P., Bower, K., Bahreini, R., Cottrell, L., Griffin, R. J., Rautiainen, J., Sun, J. Y., Zhang, Y. M., and Worsnop, D. R.: Ubiquity and dominance of oxygenated species in organic aerosols in anthropogenically-influenced Northern Hemisphere midlatitudes, Geophys. Res. Lett., 34, L13801, doi:10.11029/12007GL029979, 2007. 